\title{
Novel Composition of Multifunctional Sunblock from Eisenia bicyclis and Aloe vera Extracts and a Mixed Compound of Titanium Dioxide
}

\author{
Dong-Myong Kim ${ }^{1 *}$, Ju-Yeong Jung ${ }^{1}$, Hyung-Kon Lee ${ }^{1}$, Sang-Keun Park ${ }^{1}$, Yong-Seong Kwon ${ }^{1}$, Seung-Koo Yang ${ }^{2}$, In-Suk Han ${ }^{3}$ \\ ${ }^{1}$ Biotechnology Research Institute, KJM Bio Ltd, Seoul, Korea \\ ${ }^{2}$ R\&D Center of Aloe, Kim Jung Moon Aloe Ltd, Seoul, Korea \\ ${ }^{3}$ Department of Chemical Engineering, College of Engineering, The University of Utah, Salt Lake, USA
}

*Corresponding author: Dong-Myong Kim, Biotechnology Research Institute, KJM Bio Ltd, 17 Saimdang-ro, Seocho-gu, Seoul 06649, Korea

Tel.: +82 24056167

Fax: +82 24056154

Email: davidkim@aloe.co.kr

Received June 19, 2020

Revised July 23, 2020

Accepted July 31, 2020

Published September 30, 2020

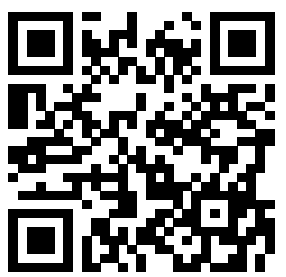

\begin{abstract}
Purpose: The objective of this study was to develop a novel composition of multifunctional sunblock (NCMFS) by combining extracts from Eisenia bicyclis ( $E$. bicyclis) and Aloe vera (A. vera) with a mixture of micron- and nano-titanium dioxide $\left(\mathrm{TiO}_{2}\right)$ powders, which are MP-100 and MPT-136, respectively, characterized by ultraviolet (UV)-blocking properties. Methods: The mixed compound was prepared by combining micron- $\mathrm{TiO}_{2}$ and nano- $-\mathrm{TiO}_{2}$ particles. The NCMFS was prepared by combining $E$. bicyclis and $A$. vera extracts with the mixed compound. The physicochemical properties (particle shape and size) of the mixed compound and $\mathrm{UV}$, infrared (IR), and thermal blocking efficiency of each compound were analyzed. Results: Analysis of the physicochemical properties of the mixed compounds showed that the optimum ratio of mixing MP-100 and MPT-136 was 2.5:7.5. Measurement of sun protection factor (SPF) and protection grade of UV-A (PA) values of $A$. vera, $E$. bicyclis, and mixed extracts and NCMFS showed that the NCMFS mixture had the highest values, which were $34.35 \pm 0.36$ and $34.87 \pm 0.36$, respectively. Similarly, upon measuring the SPF and PA values, the highest values, $34.39 \pm 0.41$ and $34.37 \pm 0.52$, respectively, were measured for NCMFS and compared to the values of each single compound or the mixed compound. In addition, it was found NCMFS has excellent antifine dust adhesion rate and water-resistant properties. Conclusion: Therefore, our results suggested that the NCMFS consisting of the mixture of $\mathrm{TiO}_{2}$ and $E$. bicyclis and $A$. vera extracts has not only UV, IR, and thermal-blocking activity but also antidust protectant and water-resistance properties.
\end{abstract}

Keywords: Eisenia bicyclis, Aloe vera, N-heterocyclic, Multifunctional, Sunblock

\section{Introduction}

화장품은 일반적으로 피부를 청결하고 아름답게 하는 것이 목적 이다. 이러한 목적을 수반하는 과정에서 잡티를 제거하며 피부를 깨 끗하고 촉촉하게 하는 기능을 가질 수 있을 뿐만 아니라, 열을 동반 한 적외선과 자외선을 차단하고, 미세먼지 등 공해물질 및 스트레 스에 의한 피부의 노화를 지연하는 기능을 갖게 할 수 있다(Forest Company, 2018).

자외선이 피부에 조사되면 다양한 피부 반응을 초래하는데, 크게
두 가지로 나뉜다. 첫 번째는 급성반응으로, 피부가 붉어지는 홍반 반응과 피부색이 검어지는 색소반응 등이 있다. 두 번째인 만성반응 으로는 광노화현상이나 광발암현상 등이 있으며, 이는 장기간 빛에 노출되면서 피부가 노화되거나 피부암을 유발하는 반응이다(Youn, 1995). 특히 피부의 노화는 크게 두 종류로 나뉜다. 첫 번째는 세월 이 흘러감에 따라 피할 수 없는 노화현상인 내인성 노화(intrinsic aging)이다. 두 번째는 광노화(photoaging)로서 오랫동안 태양광에 노출된 얼굴, 손등, 목 뒤 등의 피부에서 관찰되는 노화현상으로, 내 인성 노화현상과 자외선에 의한 노화 및 적외선에 의한 피부온도 상 
승에 따라서 피부 노화가 발생하는 것이다(Seo, 2001). 또한, 오존 층의 파괴에 따른 자외선 노출이 심화되고 있어 피부의 홍반, 주근 깨 또는 피부암 등의 원인으로 작용할 수 있다. 이에 따라, 피부노화 에 영향을 미칠 수 있는 자외선과 열을 동반한 적외선을 동시에 차 단하고 조절하여 적정 피부 상태를 유지하면서, 제형에 있어서 안정 성이 있는 안전하고 우수한 썬 제형 조성물이 요구되고 있다.

현대 사회에서 도시 지역과 산업 단지에서는 자동차 배출가스, 중 국 동부 공업지대를 지나며 날아온 황사 또는 외부 오염물을 포함하 는 미세먼지 등 공해물질은 피부 노화 및 피부 트러블의 원인이 될 수 있다. 그 속에는 크로뮴, 망간, 카드뮴, 납 등 중금속이 다량 포함 되어 있어 건강에 치명적일 수 밖에 없다(Park et al., 2005). 특히 미세먼지의 크기는 대부분 $10 \mu \mathrm{m}$ 이하이기 때문에, 평균 크기가 50 $\mu \mathrm{m}$ 이상인 일반먼지보다 훨씬 작아서 인체의 폐포까지 깊숙이 침투 해 각종 호흡기 질환의 직접적인 원인이 되며 몸의 면역 기능을 떨 어뜨린다(Shin, 2007). 이러한 침투된 미세먼지를 깨끗이 제거하지 못하면 피부에서 염증 및 트러블을 일으키는 경우가 많기 때문에, 미세먼지가 피부에 침투할 수 없도록 미연에 차단할 수 있는 제품의 필요성이 높아지고 있다.

현재 자외선 차단용으로 미립자인 이산화티타늄 $\left(\mathrm{TiO}_{2}\right)$ 이나 산화 아연 $(\mathrm{ZnO})$ 등에 의한 자외선의 산란에 의해 물리적으로 차단하는 무기 자외선 산란제와 화학적 자외선 흡수제를 혼합하여 사용하고 있다. 최근에는 유기 자외선 차단제로써 UV-A영역의 자외선을 흡 수할 수 있는 새로운 자외선 흡수제의 합성이나, 식물체와 해양미생 물을 이용한 흡수제가 연구되고 있다. 또한, 멜라닌(melanin) 색소 자체를 자외선흡수제로 사용하거나 스틸벤(stilbene) 유도체를 이 용한 합성 등이 함께 연구되고 있다(Lee, 1998; Kim et al., 2000). 또한, 천연 성분인 새싹인삼과 차풀 복합추출물, 발효 엉겅퀴 추출 물을 이용한 피부 미백효과에 관한 연구가 진행되었으며(Kim et al., 2018; Park et al., 2019), 자외선 손상 피부에 대한 미세조 류 Scenedesmus deserticola JD052 추출물의 효능이 보고되었다 (Baek et al., 2018).

대황(Eisenia bicyclis)은 갈조식물(Phaeophyta) 다시마목 (Laminariales) 미역과(Alariaceae)의 다년생 식물이다. 일반적 으로 대한민국의 울릉도 및 독도에 분포하며 조간대 심해 암반지 역 하부에서 주로 서식하고, 수심 5-10 m 부근에서 커다란 군락 을 형성한다. 통상적으로 길이는 서식처의 수심에 따라 차이가 있 으나 큰 것은 1-2 m 내외이고, 4 년까지 사는 다년생으로 유체 는 주로 봄에 나타난다. 대황에는 에콜(eckol), 플로로퓨코퓨로엑 콜(phlorofucofuroeckol-A), 다이에콜(dieckol) 및 8,8'-바이에콜 (8,8'-bieckol)과 같은 플로로탄닌계(phlorotannins) 생리활성 물질 들이 다량 함유되어 있다(Okada et al., 2004). 이들 성분들은 항균, 항염증, 항고지혈증, 항당뇨, 항산화 및 항염증 등의 다양한 기능성 을 가지고 있다고 보고되었다(Eom et al., 2013; Han et al., 2015; Jang et al., 2008; Jung et al., 2013; Okada et al., 2004). 대황
은 심해조류의 특성상 육상식물과 비교하여 엽록체가 더욱 발달되 어 있으며, 포피린(porphyrin)의 기능이 강한 비타민 B12 포피린계 로 열과 적외선 및 자외선 차단효과가 있다(Jeon et al., 2009).

알로에베라(Aloe Barbadensis Mill.)는 백합과(Liliaceae)의 다 년생 초본으로 한 곳에서 방사형으로 뻗어 나온 두껍고 다육질 의 가시가 없는 잎과 똑바로 선 노란색 혹은 빨간 꽃다발을 지 닌 줄기가 없는 식물이다. 알로에베라의 주요 성분으로는 아세만 난(acemannan), 글루코만난(glucomannan), 만노스(mannose) 와 같은 다당체(polysaccharide)를 포함하여 효소, 안트라퀴논 (anthraquinone), 비타민 및 무기질 등이 있다. 알로에의 생리활성 으로는 상처치료, 자외선 등의 화상에 의한 자극 완화, 항균, 항염 증 및 항산화 활성을 가지는 것으로 알려져 있다(Surjushe et al., 2008).

$\mathrm{N}$-헤테로 고리(N-heterocycle)는 질소 원자를 헤테로 원자로 서 포함하는 포화되거나 불포화된 5,6 또는 9원자 $\mathrm{N}$-헤테로 고 리이다. 5 원자 $\mathrm{N}$-헤테로 고리의 예로는 피롤린(pyrroline), 피 롤(pyrrole), 피라졸(pyrazole), 이미다졸(imidazole), 테트라졸 (tetrazole) 및 옥사졸(oxazole) 등이 있으며, 6원자 $\mathrm{N}$-헤테로 고 리의 예로는 피리딘(pyridine), 피페리딘(pyperidine), 피리미딘 (pyrimidine), 피라진(pyrazine) 및 우라실(uracil) 등이 있다. 이러 한 5 원자 $\mathrm{N}-$ 헤테로 고리가 벤젠고리와 결합된 형태인 9 원자 $\mathrm{N}-$ 헤 테로 고리에는 인돌린(indoline), 인돌(indole), 인다졸(indazole) 및 벤즈이미다졸(benzimidazole) 등이 속하며, 이들을 포함하는 화합 물을 유효성분으로 포함하는 조성물은 피부가 미세먼지가 부착되는 것을 방지한다는 것이 보고되었다. 이들 $\mathrm{N}-$ 헤테로 고리를 포함하 는 화합물은 피부나 물체의 표면에 존재하는 미세한 전하를 중화시 켜 미세먼지를 차단할 수 있으며, 중금속의 부착을 방지 또는 차단 하는 효과가 있다고 보고된 바 있다(LG Household \& Health Care LTD., 2017).

본 연구는 심해 해조류인 대황 및 알로에베라에서 추출한 천연추 출물과 서로 다른 크기의 미립자인 이산화티타늄의 혼합분체를 통 해 자외선과 적외선을 동시에 차단하여 다양한 피부노화 현상과 피 부 온도의 상승을 억제하는 썬 제형 조성물을 제공하기 위해 진행되 었다. 또한, $\mathrm{N}-$ 헤테로 고리를 포함하는 화합물을 더 포함하여 피부 에 미세먼지가 부착되는 양을 낮춤으로써 미세먼지로 인한 피부 트 러블 유발 등의 오염문제를 방지할 수 있는 다기능성 썬 제형 조성 물에 대한 연구가 함께 진행되었다.

\section{Methods}

\section{1. 실험재료}

본 연구에서 사용된 대황은 울릉도·독도연구소에서 지원받았으 며, 알로에베라는 (주)김정문알로에에서 구매하였다. 실험에는 순도 
99.0\%의 에탄올(Dae Jung Chemical \& Metals Co., Korea), 마이 크론 이산화티타늄 $\left(\mathrm{TiO}_{2}\right) \mathrm{MP}-100$ (Tayca Co., Japan) 및 나노 이 산화티타늄 MPT-136 (Ishihara Sangyo Co., Japan)이 사용되었 다.

\section{2. 대황 및 알로에 추출물의 제조}

대황은 알칼리 이온수를 이용해 추출한 뒤 affinity bead technique (ABT) 법으로 분리 및 정제하였다(Forest Company, 2018). 수분함량 $5 \%$ 미만으로 열풍 건조된 대황 $1.5 \mathrm{~kg}$ 에 알 칼리 이온수 $15 \mathrm{~kg}$ 을 넣고 환류냉각기(냉각 콘덴서)가 달린 추 출기(Extraction System B-811; BUCHI Labortechnik AG, Switzerland)에서 $55^{\circ} \mathrm{C}$ 로 $24 \mathrm{~h}$ 동안 중탕 조건하에서 추출하였다. 온도가 감소하기 전에 100 mesh 여과지로 여과한 후 여액을 3000 $\mathrm{rpm}$ 으로 원심분리 시켜 불순물을 제거한 상층액을 취한 후, $-40^{\circ} \mathrm{C}$ 의 동결건조기(FDU-2100; EYELA, Japan)에서 $24 \mathrm{~h}$ 동안 건조하 여 $200 \mathrm{~g}$ 의 고형분을 얻었다. 이 고형분 $200 \mathrm{~g}$ 에 에탄올 $1 \mathrm{~kg}$ 을 가 하여 천천히 교반하며 고형분에 존재하는 점액성분 이외의 물질 및 색소물질을 제거한 후 $1.0 \mu \mathrm{m}$ 필터로 여과한 후 건조하여 $180 \mathrm{~g}$ 의 고형분을 얻었다.

겉껍질을 제거한 알로에베라의 점액부위 $1.5 \mathrm{~kg}$ 역시 대황과 같 은 방법으로 추출 및 건조하여 $100 \mathrm{~g}$ 의 고형분을 얻었다. 이를 같은 방법으로 정제하여 $80 \mathrm{~g}$ 의 고형분을 얻었다.

\section{3. 혼합분체의 제조}

입자의 직경이 $0.2-1.0 \mu \mathrm{m}$ 범위인 $\mathrm{MP}-100$ 과 직경 5-100 nm 범위인 MPT-136을 이용하여 융복합 혼합분체를 제조하였다. 융 복합 혼합분체의 적외선 및 열 차단과 자외선 차단에 대한 상승효과 를 비교하기 위해, MP-100과 MPT-136의 중량비를 다르게 하여 코팅공정과 혼합공정에 각각 기계적 코팅 시스템(Mechano fusion system; Nobita, Hosokawa Micron Corp., Japan) 및 브이혼합믹 서(V-Mixer FML; Henschel Mixing Technology, Germany)을 사 용하여 $650 \mathrm{rpm}$ 에서 $7 \mathrm{~min}$ 동안 실시하였다 (Table 1).

\section{4. 혼합분체를 이용한 썬 제형 조성물 제조 및 인체 피부적용실험}

앞에서 제조한 혼합분체와 대황 및 알로에 복합추출물(대황:알로 에 $=0.67: 0.33)$ 을 이용해 썬 제형 조성물을 제조하였다. 호모믹서
(M2-2.5; TK Prinix, Japan)로 5,500 rpm 회전속도를 유지하면 서 오일상에 혼합분체 및 복합추출물을 첨가하고 $20 \mathrm{~min}$ 동안 분산 시킨 후, 다시 호모믹서로 $5,500 \mathrm{rpm}$ 회전속도를 유지하면서 오일 상에 수상을 천천히 투입한 후 $15 \mathrm{~min}$ 유화시켜 Table 2 의 균일한 썬 제형 조성물을 제조하였다.

분체의 균일한 분산을 위하여, 분산매와 분산제로 구성된 오일상 에 비교하고자 하는 분체를 각각 투입한 후 아지믹서(Agi-Mixer; Hanyang Instruments, Korea)로 $200 \mathrm{rpm}$ 에서 $5 \mathrm{~min}$ 전처리한 후에 3롤밀(type80/1342; EXAKT Appartebau GmBH, Germany) 을 이용하여 3 회 균질화 시켜 분체 분산액을 제조하였다. $\mathrm{W} / \mathrm{O}$ (water-in-oil) 타입의 썬 제형 조성물을 제조하기 위해 유상에 분 체 분산액을 투입한 후 아지믹서로 $200 \mathrm{rpm}$ 으로 $5 \mathrm{~min}$ 균일하게 분산시켰다. 균일하게 용해된 수상을 호모믹서 $2,000 \mathrm{rpm}$ 하의 유상 에 수상을 투입한 후, 수상이 완전히 투입되면 호모믹서 3,000 rpm 에서 $10 \mathrm{~min}$ 균질화하였다.

본 조성물을 이용해 피부에서의 효능을 알아보기 위하여 헬싱키 선언에 근거한 윤리규정, 식품의약품안전처의 의약품, 의약외품, 화장품 및 의료기기 검사기관 지정 등에 관한 규정, 의약품 임상시 험 관리기준, 화장품 인체적용시험 및 효력시험 가이드라인, 화장 품 표시 광고 실증을 위한 시험방법 가이드라인, 기능성화장품의 유 효성 평가를 위한 가이드라인, 보건복지부의 생명윤리 및 안전에 관 한 법률에 따라 중앙대학교 피엔케이피부임상연구센타(P\&K Skin Research Center)에 의뢰하여 2016년 12월 12일부터 2016년 12월 27일까지 자외선, 적외선 및 열 차단에 대한 인체 피부적용시험을 실시하였다(PNK-16D12-E1R).

\section{5. 혼합분체의 물성분석}

본 연구에서 사용된 혼합분체의 형태와 특성을 분석하기 위해 주사전자현미경(Scanning Electron Microscope; SEM, JSM7600F; JEOL Ltd., Japan)을 이용하여 20,000배, 40,000배 및 100,000 배의 배율에서 표면 형상을 평가하였다.

혼합분체의 입자 크기 및 입도 분포의 변화는 레이저회절입도분 석기(SALD-2001; Shimadzu Co Ltd., Japan)를 이용하여 습식 방 법으로 측정하였다. 제조된 혼합분체는 $0.1 \%$ 농도로 에탄올에 희석 시켜 $5 \mathrm{~min}$ 동안 초음파 처리 후에 용매로 에탄올이 사용된 레이저 회절입도분석기에 투입하여 측정하였다.

Table 1. Processing conditions of mixed compounds

\begin{tabular}{lcc}
\hline & IRatio of MP-100:MPT-136 ${ }^{1)}$ & Process \\
C1 & $2.5: 7.5$ & Coating \\
C2 & $4.5: 5.5$ & Coating \\
M1 & $2.5: 7.5$ & Mixing \\
M2 & $4.5: 5.5$ & Mixing \\
\hline
\end{tabular}

${ }_{11}^{1} \mathrm{MP}-100$ and MPT-136 represent micron-titanium dioxide $\left(\mathrm{TiO}_{2}\right)$ and nano-TiO, , respectively. 


\section{6. 각 추출물, 혼합분체 및 썬 제형 조성물에 대한 자외선 차단효과}

알로에베라 및 대황 각각의 추출물, 복합추출물, $\mathrm{MP}-100$, MPT-136, 혼합분체 및 썬 제형 조성물에 대한 자외선 차단효과 를 측정하였다. 그 과정은 화장품법 제4조 및 같은 법 시행규칙 제 9조, 식품의약품안전처 고시 제2016-98호의 별표 3의 자외선 차 단효과 측정방법 및 기준에 따라 측정하였다. 시료 $2.0 \mathrm{mg} / \mathrm{cm}^{2}$ 을 transpore TM tape (3M, USA)의 비접착면에 골고루 점적하고 골 무를 낀 손가락을 이용하여 균일하게 바른 후 $15 \mathrm{~min}$ 건조하여 측 정 시료를 준비했다. 먼저 기질로서 transpore TM tape를 부착시 켜 film holder에 보정 및 감도를 조정하여 레퍼런스 스캔(reference scan)을 진행한 후, 자외선 차단 수치 측정기(SPF-290 analyzer; The Optometics Group, USA)를 이용하여 시료를 측정하였다. 측 정 시 무작위로 12 회 스캔하여 평균값을 얻었고, 20 대 이상의 피험 자 10 명(남·여 각각 5 명)을 이용한 in vivo의 sun protection factor $(\mathrm{SPF})$ 와 protection grade of $\mathrm{UV}-\mathrm{A}(\mathrm{PA})$ 측정 결과로 나타냈다.

\section{7. 썬 제형 조성물에 대한 자외선과 적외선 및 열 차단 효과}

피험자를 대상으로 썬 제형 조성물을 사용하여 코로나 자외선/적 외선 열화상 카메라(CoroCAM8; UVIRCO LTD., Japan)의 사용 전 후의 비교 사진을 촬영하였다. 썬 제형 조성물을 손등 및 얼굴 부위 의 피부에 $2.0 \mathrm{mg} / \mathrm{cm}^{2}$ 만큼 도포하고 도포 전과 도포 후의 자외선 카메라 이미지를 획득하였다. 또한, 썬 제형 조성물에 대한 적외선 및 열차단 효과를 측정하기 위하여 썬 제형 조성물을 얼굴과 허벅지 부위의 피부에 $2.0 \mathrm{mg} / \mathrm{cm}^{2}$ 을 도포하여 도포 전과 도포 후의 이미지 를 획득하였다. 자외선 수치는 평균값과 합계, 열화상은 자동 auto flat field correction (0.5s, auto level and span), 실화상은 auto low light 및 manual back light compensation 기능으로 처리하였 다.

\section{8. 썬 제형 조성물에 대한 미세먼지 부착 평가}

미세먼지 부착 수치는 환경부 고시 제2015-247호, 환경분야 시 험·검사 등에 관한 법률, 제 6 조 제 1 항에 따른 대기오염공정시험기 준(환경부고시 제2014-58호, 2014.4.7.) 개정 고시시항에 따라 평 가하였다. Poly-(methyl methacrylate) (PMMA) 플레이트에 1.3 $\mathrm{mg} / \mathrm{cm}^{2}$ 의 인공피지를 도포 후 $15 \mathrm{~min}$ 건조시켰다. 시험 제형을 건 조한 인공피지 위에 동일한 양으로 도포 후 $15 \mathrm{~min}$ 건조시켰다. 챔 버의 내부 상단에 PMMA 플레이트를 부착하고 챔버 하단에 있는 팬 을 가동하여 $0.5 \mathrm{~g}$ 의 대체 미세먼지(공시재료명: LM-YG0510, 탄 산스트론튬, 알루미나, 산화유로폼, 산화디스프로슘 포함)를 $5 \mathrm{~min}$ 노출한 후 확대경을 이용하여 플레이트당 4 point로 UV 이미지를 촬영했다. ImagePro Plus를 이용하여 먼지 부착 면적을 분석하여, 3 회 실험한 결과로 샘플을 대조하여 미세먼지 부착도를 계산하여 평 가하였다.

\section{9. 썬 제형 조성물에 대한 내수성 평가}

썬 제형 조성물에 대한 내수성 평가는 화장품법 제4조 및 같은 법 시행규칙 제9조, 식품의약품안전처 고시 제2016-98호 내수성 자 외선 차단지수 측정방법 가이드라인의 지속내수성 제품 시험방법과 식약처 고시 '기능성 화장품 기준 및 시험방법' 중 '자외선 차단 기능 성시험법'에 따라 진행하였다.

Table 2. Sun formulation composition of mixed compounds and complex extracts

\begin{tabular}{lc}
\hline Components & Percentage (\%) \\
Complex extracts of Eisenia bicyclis and Aloe vera (0.67:0.33) & $0.5-1.5$ \\
Mixed compounds of MP-100 and MPT-136 & $15.0-16.0$ \\
Cyclomethicone & $6.0-7.0$ \\
Neopentyl glycol diethylhexanoate & $7.0-8.0$ \\
Polyglyceryl-6 polyricinoleate & $0.5-1.5$ \\
Dicaprylyl carbonate & $3.0-5.0$ \\
Dimethicone & $3.0-5.0$ \\
Cetyl PEG/PPG-10/1 Dimethicone & $1.5-3.0$ \\
Quaternium 18-hectorite & $0.5-1.5$ \\
Butylene glycol & $6.0-8.0$ \\
Glycerin & $2.0-4.0$ \\
Methylparaben & $0.1-0.5$ \\
Sodium chloride & $0.5-1.5$ \\
Bis-ethylhexyloxyphenol methoxyphenyl triazine & $1.0-3.0$ \\
Vitamin B12 (cyanocobalamin) & $0.1-0.5$ \\
Purified water & Remains \\
\hline
\end{tabular}



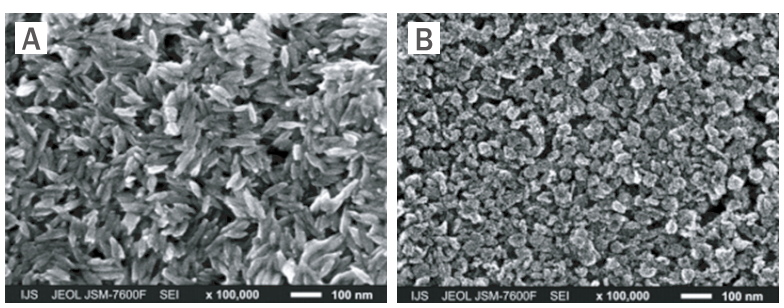

Figure 1. SEM image of MP-100 and MPT-136, which are micron- and nano-titanium dioxide $\left(\mathrm{TiO}_{2}\right)$ powders, respectively $(\times 100,000)$.

(A) MP-100; (B) MPT-136. SEM, scanning electron microscope.

\section{0. 통계분석}

각 시료 간의 차이를 비교하기 위해 통계처리를 실시하였다. 모 든 시료에 대하여 3 회 반복 추출하였으며, 각 자료는 평균과 표 준오차로 나타내었다. 통계 분석에는 SAS (Statistical analysis program) software version 8 (SAS Institute Inc., USA)가 이용 되었으며, $95 \%$ 유의수준에서 평균값과 표준편차를 던컨의 다중검 정 시험으로 각 방법 간의 유의적인 차이를 확인하였다.

\section{Results and Discussion}

\section{1. 혼합분체의 물성분석}

자외선 차단분체로 알려진 MP-100와 MPT-136의 SEM 이미 지를 Figure 1에 나타냈다. 혼합분체에 사용된 $\mathrm{MP}-100$ 의 SEM 사진(Figure $1 \mathrm{~A}$ )을 통해 입자 표면은 매끄럽고 입자 형태는 판상 의 구조로 입자크기가 큰 것을 알 수 있었다. 또한, MPT- 136 의 $\mathrm{SEM}$ 사진(Figure $1 \mathrm{~B}$ )을 통해 입자 형태는 구형 또는 방추형 구조 이며 입자 크기가 매우 작고 응집체를 형성하고 있음을 알 수 있었 다. $\mathrm{MP}-100$ 과 $\mathrm{MPT}-136$ 를 $2.5: 7.5$ 비율로 코팅한 혼합분체를 20,000 배 및 40,000 배에서 각각 관찰한 주사전자현미경 이미지는 Figure 2에 나타냈다. MP-100의 매끄러운 입자 표면(Figure 1A) 에 구형 혹은 방추형의 작은 입자들인 MPT-136 (Figure 1B)가 부 착되어, 거친 표면을 가진 혼합분체(Figure 2)가 형성되었음을 알 수 있었다. 이는 MP-100의 표면 위에 MPT-136이 불연속성 코팅 (discrete coating)구조로 되어 있음을 나타낸다.

입도 분석 결과, 혼합분체에 사용된 $\mathrm{MP}-100$ 의 평균 입자크기는 $550 \mathrm{~nm}$ 이었고 MPT-136의 평균 입자크기는 $25 \mathrm{~nm}$ 이었다. 혼합 분체의 평균 입자크기는 MPT-136의 중량 비율이 증가할수록 각 각 $650 \mathrm{~nm}$ 에서 $1.5 \mu \mathrm{m}$ 까지의 범위로 증가하는 경향을 보였다. 또 한, 제조된 혼합분체는 MPT-136의 중량 비율이 높아질수록 평균 입자크기는 증가하는 경향을 나타냈다. SEM 사진과 평균입자크기 및 입자크기 분포를 통하여 얻어진 결과로 미루어 보았을 때, 혼합
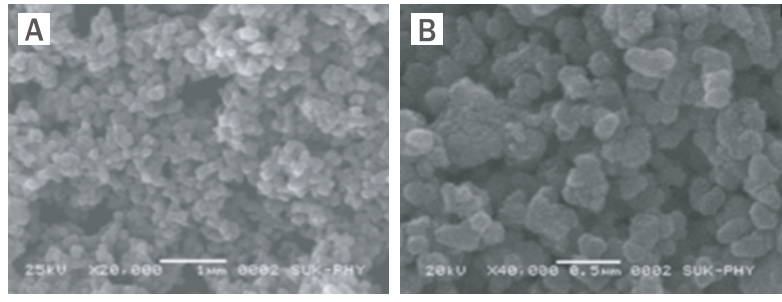

Figure 2. SEM image of MP-100/MPT-136 mixed compound in ratio of 2.5:7.5.

MP-100 and MPT-136 represent micron-titanium dioxide $\left(\mathrm{TiO}_{2}\right)$ and nano- $\mathrm{TiO}_{2}$, respectively. (A) $\times 20,000$; (B) $\times 40,000$. SEM, scanning electron microscope.

분체 형성의 최적 비율은 $2.5: 7.5$ 이었다. 따라서 본 비율의 혼합 분체를 이용해 후속 실험을 진행하였다.

\section{2. 각 추출물, 혼합분체 및 썬 제형 조성물에 대한 자외선 차단효} 과

각 추출물, 혼합분체 및 추출물이 함유된 썬 제형 조성물의 자외 선 차단효과를 비교하였다. 측정은 알로에베라 추출물, 대황 추출 물, 대황 및 알로에 복합추출물 및 추출물이 함유된 썬 제형 조성물 의 자외선 차단효과(Figure $3 \mathrm{~A}$ )와 $\mathrm{MP}-100, \mathrm{MPT}-136$, 혼합분체 및 썬 제형 조성물의 자외선 차단효과(Figure $3 \mathrm{~B}$ )로 나누어 실시하 였다.

알로에, 대황, 복합추출물 및 썬 제형 조성물에서 $\mathrm{SPF}$ 수치의 경 우 각각 $6.75 \pm 0.21,10.29 \pm 0.35,16.21 \pm 0.42$ 및 $34.35 \pm 0.36$ 를 나타냈으며, $\mathrm{PA}$ 수치의 경우 각각 $6.26 \pm 0.13,9.56 \pm 0.12$, $17.34 \pm 0.27$ 및 $34.87 \pm 0.36$ 을 나타냈다. 이러한 결과는 각 단독 추출물에 비하여 복합 추출물과 대황 및 알로에베라 추출물이 함유 된 썬 제형 조성물이 모두 SPF 수치 및 $\mathrm{PA}$ 수치를 유의적으로 상승 시키는 것을 확인하였다.

마찬가지로, MP-100, MPT-136, 혼합분체 및 썬 제형 조성물 에서 $\mathrm{SPF}$ 수치의 경우 각각 $8.82 \pm 0.32,16.88 \pm 0.51,26.85 \pm$ 0.25 및 $34.39 \pm 0.41$ 를 나타냈으며, $\mathrm{PA}$ 수치의 경우 각각 $8.45 \pm$ $0.27,15.86 \pm 0.36,29.87 \pm 0.21$ 및 $34.37 \pm 0.52$ 을 나타냈다. 이 러한 결과에 따라 $\mathrm{MP}-100$ 과 $\mathrm{MPT}-136$ 의 경우 $\mathrm{PA}+++$ 등급에, 혼합분체는 $\mathrm{PA}++++$ 등급에, 썬 제형 조성물은 $\mathrm{PA}++++$ 이상의 등급에 해당하는 것을 확인하였다. 또한, 각 단독분체에 비하여 혼 합분체 그리고 대황 및 알로에베라 추출물이 함유된 썬 제형 조성 물이 모두 $\mathrm{SPF}$ 수치 및 $\mathrm{PA}$ 수치를 유의적으로 상승시키는 것을 의 미한다고 볼 수 있었다.

\section{3. 썬 제형 조성물에 대한 자외선과 적외선 및 열 차단효과}

썬 제형 조성물에 대한 자외선과 적외선 및 열 차단효과를 확인 하기 위해 피험자를 대상으로 코로나 자외선/적외선 열화상 카메라 
A

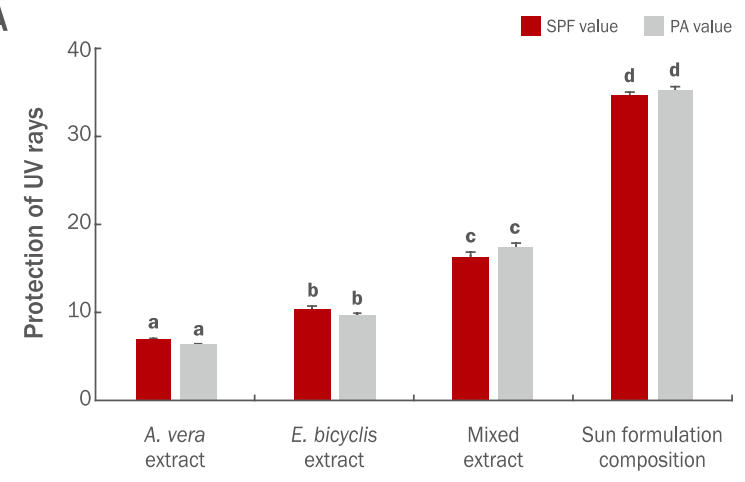

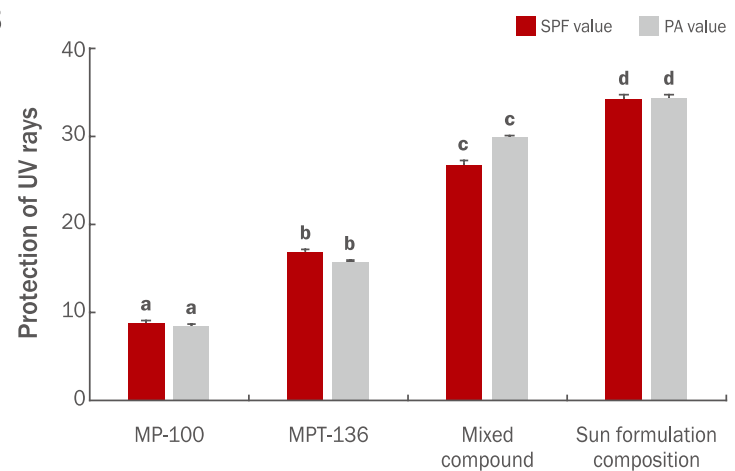

Figure 3. Values of SPF and PA.

(A) SPF and PA values of Aloe vera extract, Eisenia bicyclis extract, mixed extract and sun formulation composition resulting from in-vivo experiments. (B) The SPF and PA values of MP-100, MPT-136, mixed compound, and sun formulation composition resulting from the invivo experiments. MP-100 and MPT-136 represent micron-titanium dioxide $\left(\mathrm{TiO}_{2}\right)$ and nano-TiO ${ }_{2}$, respectively. Values marked by different letters indicate statistically significant differences with $p<0.05$ (ANOVA with Duncan post hoc test). Error bars indicate standard deviation. SPF, sun protection factor; PA, protection grade of UV-A .

를 통해 사용 전후의 비교 사진을 촬영하였다.

썬 제형 조성물을 손등 및 얼굴 부위의 피부에 도포한 뒤 자외선 카메라를 이용해 촬영한 결과, 도포된 손등 및 얼굴의 피부에서 전 체적으로 검게 변한 것을 확인하였다(Figure 4). 이를 통해 썬 제형 조성물이 자외선 차단 효과를 나타낸 것을 알 수 있었다.

썬 제형 조성물 도포 전후의 얼굴 및 허벅지 부위를 적외선 열화 상 카메라로 촬영한 결과는 Figure 5 에 나타내었다. 적외선 열화상 카메라로 촬영하는 경우 체온이 높을수록 붉은색을, 낮아질수록 푸 른색을 나타낸다. 썬 제형 조성물의 도포 후에 얼굴과 허벅지 부분 에서 붉은색이 적고 녹색 및 푸른색 부분이 넓은 것이 확인되었다. 이 결과를 프로그램을 통하여 환산한 결과, 평균적으로 얼굴에서는 $15 \pm 5^{\circ} \mathrm{C}$ 낮은 것을, 허벅지 부위에서는 $25 \pm 5^{\circ} \mathrm{C}$ 가량 낮은 것을 알 수 있었다. 이를 통해 썬 제형 조성물이 열 발생의 원인인 적외선

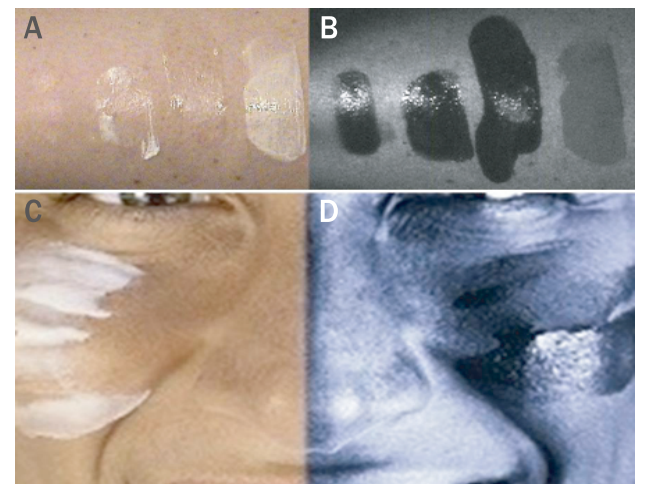

Figure 4. UV camera image of back of hand and face used to investigate the effect of UV protection.

(A) Back of hand before and (B) after spreading of mixture. (C) Face before and (D) after spreading of mixture. UV, Ultraviolet.
및 열선의 차단효과를 가지는 것을 확인하였다.

자외선은 파장대에 따라서 UV-A (315-400 nm), UV-B (280-315 nm) 및 UV-C (100-280 nm)로 분류된다. 이때 UV-C 영역은 지구 대기권에 의해 사실상 완전히 차단되어 있기 때문에 사람의 건강에 미치는 영향은 거의 없다. UV-B는 홍반(화상), 피 부암 유발 및 면역 억제 작용의, $\mathrm{UV}-\mathrm{A}$ 는 피부 노화의 원인이 된다 (Gallagher \& Lee, 2006). 이러한 자외선에 의한 피부 자극을 방지 하기 위해서 자외선 차단제가 사용되고 있다. 본 연구에서는 무기 자외선 차단 성분인 마이크론 이산화티타늄 MP-100 및 나노 이산 화티타늄 MPT-136를 혼합한 복합분체에 대황과 알로에베라의 복 합추출물을 혼합하고 다기능성 썬 제형 조성물을 제조하여 차단 효 과를 확인하였다. 그 결과, 앞선 $\mathrm{SPF}$ 수치 및 $\mathrm{PA}$ 수치 측정 결과와 상응하면서 자외선뿐만 아니라 적외선 및 열 차단효과를 가지는 것

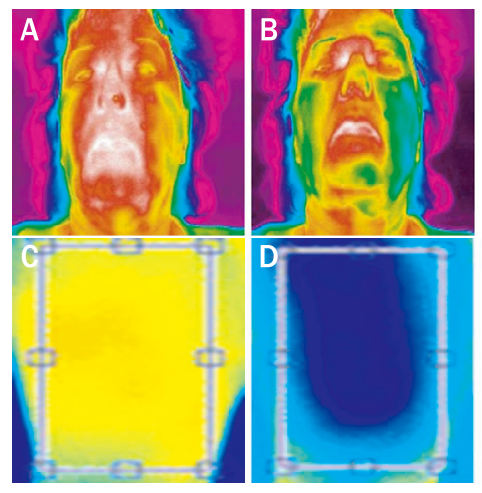

Figure 5. Infrared thermal camera image of face and thigh to investigate the effect of infrared and thermal protection.

(A) Face before and (B) after spreading mixture of mixture. (C) Thigh before and $(D)$ after spreading of mixture. 
을 확인할 수 있었다. 복합추출물의 성분 중 하나인 대황은 독도 및 울릉도 인근의 심해에서 자생하는 미세조류이다. 빛이 잘 들지 않 는 심해에 서식하는 미세조류는 적은 양의 빛이라도 흡수하는 성 질이 매우 강하여 광합성 효율이 높은 것으로 알려져 있다(Cho et al., 2006; Zijffers et al., 2010). 본 연구의 결과로 미루어 보았을 때, 대황을 이용한 자외선 차단제를 제조할 시, 자외선이 흡수되어 피부 내부로 투과되는 것을 방지하는 것으로 사료된다. 또한, 알로 에베라는 상처치료, 자극 완화, 향균작용 등의 다양한 생리활성 기 능을 가지며 항산화, 주름 개선 및 피부 탄력성 유지 등의 효과를 위한 원료로 사용되어 왔다(Surjushe et al., 2008; Yoon \& Pyo, 2013). 따라서 이 두가지 천연물의 복합추출물을 이용한 썬 제형 조성물은 자외선, 적외선 및 열에 의한 피부 노화를 억제하며 다양 한 기능성을 가진 것으로 생각된다.

\section{4. 썬 제형 조성물에 대한 미세먼지 부착 평가}

썬 제형 조성물과 환경부 공시 재료의 미세먼지 부착도를 비교한 결과, 썬 제형 조성물은 $11.48 \pm 1.25 \%$ 의 상대 부착도를 나타냈다. 비교군인 공시재료의 상대 부착도는 최소 $82.54 \%$, 최대 $90.27 \%$ 로, 환경부 고시 기준인 $1 / 2$ 미만의 상대 부착률은 $41.27 \%$ 미만이 었다. 썬 제형 조성물은 환경부 고시 기준보다 횔씬 낮게 평가되어 우수한 미세먼지 부착 방지 효과가 있는 것을 확인하였다.

\section{5. 썬 제형 조성물에 대한 내수성 평가}

썬 제형 조성물에 대한 내수성 평가 결과, 내수성비 신뢰구간이 $82.67 \%$ 으로 측정되었으며, 상기의 썬 제형 조성물은 내수성비 신 뢰구간이 식품의약품안전처에서 제시한 기준인 $50 \%$ 이상으로 아 주 우수한 지속내수성이 확인되었다.

자외선 차단제의 내수성(water resistance)이란 피부 표면에 도 포된 후 물, 땀, 신체적 활동에도 불구하고 피부에서 제거되지 않고 남아 있으려는 성질을 뜻한다. 대부분의 자외선 차단제는 물리적 으로 제거되거나 흡수되지 않는 이상 피부에서 수 시간동안 그 효 과를 유지하는 것으로 알려져 있지만, 바람이나 열과 같은 외부 현 상, 물기나 땀, 마찰 또는 피부에서부터 제거할 수 있는 여러 인자 들에 의해 효과가 감소된다. 그러나 이 내수성은 수영이나 기타 활 동 중에도 차단제가 씻겨 나가지 않고 피부에 밀착된 상태로 화상 이나 피부손상 등을 방지해야 하기 때문에 자외선 차단제의 매우 중요한 요소 중 하나로 꼽힌다(Agin, 2006; Youn, 1997; Yoon et al., 2006). 본 연구에서 사용된 썬 제형 조성물에 대한 내수성 평 가 결과가 식품의약품안전처 기준인 $50 \%$ 보다 $30 \%$ 이상 높은 것 으로 미루어 보았을 때, 혼합분체에 대황 및 알로에베라 복합추출 물을 혼합할 경우 자외선 차단 효과의 내수성이 우수한 것으로 생 각된다.

\section{Conclusion}

본 연구는 우리나라 영토인 독도에 자생하는 심해 해조류 중 하 나인 대황 추출물 및 알로에베라 복합추출물을 함유함으로써 피부 의 열을 조절하여 피부 온도가 상승하는 것을 억제하는 새로운 자외 선 차단제 제조를 목적으로 진행되었다. 더불어서 $\mathrm{N}-$ 헤테로 고리를 포함하는 화합물을 함유하여 미세먼지의 피부 부착률을 낮춤으로써 미세먼지로 인한 피부 트러블 유발 등의 오염문제를 방지하는 다기 능성 썬 제형 조성물이 연구되었다.

적외선 및 열 차단분체인 마이크로 이산화티타늄과 나노 이산화 티타늄을 함께 이용한 혼합분체의 물성분석을 통해 최적 중량 비율 인 2.5:7.5를 확인하였다. 혼합분체에 대황 및 알로에베라 복합추출 물을 혼합하여 $\mathrm{SPF}$ 수치와 $\mathrm{PA}$ 수치를 측정한 결과, 각각 단일 차단 입자, 혼합분체, 썬 제형 조성물의 순서대로 높은 수치를 보였다. 또 한, 자외선/적외선 열화상 카메라를 통해 썬 제형 조성물의 사용 전 후의 비교 사진 촬영을 통해 자외선, 적외선 및 열선의 차단 효과를 가지는 것을 확인하였다. 환경부 공시 재료와의 미세먼지 부착도를 비교한 결과, 환경부 고시 기준보다 횔씬 낮게 평가되어 우수한 미 세먼지 부착 방지 효과가 있음을 확인하였으며, 내수성 평가 실험을 통해 다기능성 썬 제형 조성물의 자외선 차단 효과의 내수성이 확인 되었다.

본 연구를 통해서 무기 자외선 차단제인 이산화티타늄 혼합분체 의 최적 중량 비율을 규명하였다. 이에 대황 및 알로에베라 복합추 출물을 함께 혼합하여 자외선, 적외선 및 열선을 동시에 차단하면서 기존의 다른 썬 제형들에 비해 높은 자외선 차단 수치를 가질 뿐만 아니라 우수한 미세먼지 부착 방지율과 내수성을 갖는 새로운 다기 능성 썬 제형 조성물이 제조되었다. 최근 현대사회에 당면한 문제인 오존층 파괴 및 대기오염에 대비하여 피부의 노화, 트러블 및 피부 암 등의 다양한 질환을 방지하는 다기능성 썬 제형이 연구되었다는 점에서 의의가 있다.

\section{Acknowledgements}

본 논문은 2018년도 중소벤처기업부와 서울특별시의 재원으 로 기술개발 지원사업의 지원을 받아 수행된 연구임(과제번호: S2594138)

\section{Author's contribution}

HKL and SKP performed extraction and physiochemical experiments. JYJ performed the preparation of the samples, formulation, stability and efficacy test. ISH, SKY and YSK assisted with experimental design and analyzed data. DMK designed this project and wrote the manuscript with assistance from JYJ. 
Author details

Dong-Myong Kim (Chief Technical Officer), Biotechnology Research Institute, KJM Bio Ltd, 17 Saimdang-ro, Seocho-gu, Seoul 06649, Korea; Ju-Yeong Jung (Senior Researcher), Biotechnology Research Institute, KJM Bio Ltd, 17 Saimdang-ro, Seocho-gu, Seoul 06649, Korea; Hyung-Kon Lee (Senior Researcher), Biotechnology Research Institute, KJM Bio Ltd, 17, Saimdang-ro, Seocho-gu, Seoul 06649, Korea; Sang-Keun Park (Senior Researcher), Biotechnology Research Institute, KJM Bio Ltd, 17, Saimdang-ro, Seocho-gu, Seoul 06649, Korea; Yong-Seong Kwon (Research Director), Biotechnology Research Institute, KJM Bio Ltd, 17, Saimdang-ro, Seocho-gu, Seoul 06649, Korea; Seung-Koo Yang (Research Director), R\&D Center of Aloe, Kim Jung Moon Aloe Ltd, 15, Saimdang-ro, Seocho-gu, Seoul 06649, Korea; In-Suk Han (Professor), Department of Chemical Engineering, College of Engineering, The University of Utah, 201 Presidents'Cir, Salt Lake City, UT 84112, USA.

\section{References}

Agin PP. Water resistance and extended wear sunscreens. Dermatologic Clinics, 24: 75-79, 2006.

Baek JS, Jin SE, Kang SH, Park CS, Jeong JH, Yi SW, Kim YS. Effects of Scenedesmus deserticola JD052 extracts on UV-induced skin irritation. Asian Journal of Beauty and Cosmetology, 16: 71-81, 2018.

Cho ES, Lee PY, Oh HJ, Choi YS, Choi YH, Lee SG. Evaluation

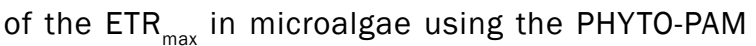
fluorometer. Journal of Environmental Science International, 15: 727-735, 2006.

Eom SH, Lee DS, Kang YM, Son KT, Jeon YJ, Kim YM. Application of yeast Candida utilis to ferment Eisenia bicyclis for enhanced antibacterial effect. Applied Biochemistry and Biotechnology, 171: 569-582, 2013.

Forest Company. Multifunctional sun formulation composition. KR Patent 10-2020-0025673, 2018.08.31.

Gallagher RP, Lee TK. Adverse effects of ultraviolet radiation: a brief review. Progress in Biophysics and Molecular Biology, 92: 119-131, 2006.

Han HN, Eom SH, Kim JH, Kim DH, Kim SH, Kim YH, Yeom $\mathrm{SH}$, Kim YM. Effects of lactic acid bacterial fermentation on the antioxidant and anti-inflammatory activity of brown algae Eisenia bicyclis extract. Korean Journal of Fisheries and Aquatic Sciences, 48: 151-157, 2015.

Jang $\mathrm{YH}$, Choi SW, Cho SH. Effect of Eisenia bicyclis and its pill on serum lipid status in rats fed high fat diet. Journal of Nutrition and Health, 41: 5-12, 2008.

Jeon HY, Kim JK, Seo DB, Lee SJ. Effects of chlorophyll a on UVB-induced cellular responses and Type I pN collagen synthesis in vitro. Korean Journal of Food Science and Technology, 41: 700-705, 2009.

Jung HA, Jin SE, Ahn BR, Lee CM, Choi JS. Anti-inflammatory activity of edible brown alga Eisenia bicyclis and its constituents fucosterol and phlorotannins in LPSstimulated RAW264. 7 macrophages. Food and Chemical Toxicology, 59: 199-206, 2013.

Kim KD, Lee YD, Park SS, Youn SH, Lee SH. The effect and stability of plant extract ingredient as uv absorber. Journal of the Society of Cosmetic Scientists of Korea, 26: 41-58, 2000.

Kim KW, Choi YH, Kim BL, Kim YG, Seong RS, Han MH, Kim GA, Choi MJ, Jeong YG. Determination of anti-oxidative and whitening effects of complex extracts obtained from sprout Panax ginseng C.A. Meyer and Cassia nomame (Sieb.) Honda on skin. Asian Journal of Beauty and Cosmetology, 16: 309-320, 2018.

Lee OS. The future of R\&D in cosmetic. Journal of The Society of Cosmetic Scientists of Korea, 24: 16-39, 1998.

LG Household \& Health Care LTD. Cosmetic composition for protecting microdust. KR Patent, 10-1855-4380000, 2017.05.12.

Okada Y, Ishimaru A, Suzuki R, Okuyama T. A new phloroglucinol derivative from the brown alga Eisenia bicyclis: potential for the effective treatment of diabetic complications. Journal of Natural Products, 67: 103-105, 2004.

Park EJ, Kang MS, You DE, Kim DS, Yu SD, Chung KH, Park K. Health risk assessment of heavy metals in fine particles collected in Seoul metropolitan area. Environmental Health and Toxicology, 20: 179-186, 2005.

Park YE, Kwon GS, Kim BH, Lee JB. Evaluation of the usefulness of the fermented thistle (Cirsium japonicum) with Lactobacillus rhamnosus BHN-LAB105 for antioxidative and whitening effects. Asian Journal of Beauty and Cosmetology, 17: 1-13, 2019. 
Seo JY. Skin aging from phenotype to mechanism. Korean Journal of Investigative Dermatology, 8: 187-194, 2001.

Shin DC. Health effects of ambient particulate matter. Journal of the Korean Medical Association, 50: 175-182, 2007.

Surjushe A, Vasani R, Saple DG. Aloe vera: a short review. Indian Journal of Dermatology, 53: 163-166, 2008.

Yoon MY, Pyo YH. A study on the Aloe vera extract as the anti-againg cosmetic ingredient. Journal of the Korean Society of Cosmetology, 19: 931-936, 2013.

Yoon TJ, Park SY, Koh JS. The measurement of SPF in waterresistant sunscreen. Korean Journal of Investigative
Dermatology, 13: 105-110, 2006.

Youn Jl. Effects of ultraviolet radiation on the skin. Journal of Radiation Protection and Research, 20: 181-186, 1995.

Youn Jl. The measurement of UVA and UVB photoprotectiveness and its influencing factors. Korean Journal of Dermatology, 35: 1043-1051, 1997.

Zijffers JWF, Schippers KJ, Zheng K, Janssen M, Tramper J, Wijffels RH. Maximum photosynthetic yield of green microalgae in photobioreactors. Marine Biotechnology, 12: 708-718, 2010. 


\title{
국문초록
}

\section{대황 및 알로에 베라 복합추출물과 이산화티탄의 혼합분체로부터 새로운 다기능성 선 블록의 조성물에 관한 연구}

\author{
김동명 ${ }^{1 *}$, 정주영 ${ }^{1}$, 이형곤 ${ }^{1}$, 박상근 $^{1}$, 권용성 ${ }^{1}$, 양승구 ${ }^{2}$, 한인석 $^{3}$ \\ 1(주)케이제이엠바이오 생물공학연구소, 서울, 한국 \\ ${ }^{2}$ (주)김정문알로에 알로에연구소, 서울, 한국 \\ ${ }^{3}$ 유타대학교 공과대학 화학공학과, 살트레이크, 미국
}

목적: 본 연구에서는 자외선 차단분체와 적외선 및 열선 차단분체의 혼합분체에 대황(Eisenia bicyclis) 및 알로에(Aloe vera)의 복 합추출물을 혼합함으로써 피부 온도가 상승하는 것을 억제하는 다기능성 썬 제형 조성물(Novel Composition of Multi-Functional Sunblock, NCMFS)을 제조하였다. 방법: 마이크론 이산화티타늄과 나노 이산화티타늄을 이용해 혼합분체를 제조하였으며, 이 혼 합분체에 대황 및 알로에 추출물을 혼합하여 NCMFS를 제조하였다. 혼합분체의 물성(형태 및 입도)을 분석하였으며, 각각 자외선 차단분체, 혼합분체, 그리고 NCMFS의 자외선, 적외선 및 열 차단 효과를 분석하였다. 또한 NCMFS의 미세먼지 부착도 및 내수성 을 평가하였다. 결과: 혼합분체의 물성분석 결과, 혼합 시 최적 중량 비율인 $2.5: 7.5$ 가 확인되었다. 알로에 추출물, 대황 추출물 및 $\mathrm{NCMFS}$ 를 대상으로 $\mathrm{SPF}$ 수치와 PA 수치를 측정한 결과, 각각 $34.35 \pm 0.36$ 및 $34.87 \pm 0.36$ 로 NCMFS에서 가장 높은 값을 보였다. 마찬가지로, 단일 차단분체, 혼합분체, NCMFS를 대상으로 SPF 수치와 $\mathrm{PA}$ 수치를 측정한 결과, 각각 $34.39 \pm 0.41$ 및 $34.37 \pm 0.52$ 로 NCMFS가 가장 높은 값을 보였다. 자외선/적외선 열화상 카메라를 통해 NCMFS의 사용 전후의 비교 사진 촬영을 통해 자외선, 적외선 및 열선 차단 효과를 가지는 것이 확인되었다. 또한, 우수한 미세먼지 부착도 및 내수성을 가지는 것이 확인되었다. 결론: 본 연구를 통해 무기 자외선 차단제인 이산화티타늄 혼합분체의 최적 중량 비율을 규명하였다. 대황 및 알로에 복합추출물을 함께 혼 합하여 자외선, 적외선 및 열선을 동시에 차단함으로써 높은 자외선 수치를 가지는 다기능성 썬 제형 조성물이 확인되었다.

핵심어: Eisenia bicyclis, Aloe vera, N-heterocyclic, 다기능성, 선블록

본 논문은 2018년도 중소벤처기업부와 서울특별시의 재원으로 기술개발 지원사업의 지원을 받아 수행된 연구임(과제번호: S2594138).

\section{참고문헌}

김경동, 이용두, 박성순, 윤성화, 이석현. 자외선 흡수제로서의 식물추출성분이 안정성과 효과. 대한화장품학회지, 26 : $41-58,2000$.

김건우, 최윤희, 김병록, 김영욱, 성락선, 한민희, 김경애, 최민주, 정용기. 새싹인삼과 차풀 복합추출물의 피부 항산화 및 미백효과. 아시안뷰티화장품학술지, 16: 309-320, 2018.

박예은, 권기석, 김병혁, 이중복. Lactobacillus rhamnosus BHN-LAB105를 이용한 발효엉겅퀴의 항산화 및 미백효과 에 대한 유용성 평가. 아시안뷰티화장품학술지, 17: 1-13, 2019.

박정은, 강미선, 유대은, 김대선, 유승도, 정규혁, 박광식. 서울북부 지역 미세먼지에 함유된 유해 중금속의 분석 및 건강

위성평가. 한국독성보건학회지, 20: 179-186, 2005.

백준석, 진세은, 강승혜, 박찬선, 정재훈, 이상원, 김영수. 자외선 손상 피부에 대한 Scenedesmus deserticola JD052 추

출물의 효능. 아시안뷰티화장품학술지, 16: 71-81, 2018.

서진영. 피부노화이 특징과 발생기전. 대한피부연구학회지, 8: 187-194, 2001. 
윤재일. UVA, UVB 차단지수 측정방법과 이에 영향을 미치는 요인. 대한피부과학회지, 35: 1043-1051, 1997.

윤재일. 자외선에 의한 피부반응. 방사선학회지, 20: 181-186, 1995.

윤미연, 표영희. 항노화 화장품 소재로서의 알로에 베라 추출물에 관한 연구. 한국미용학회지, 19: 931-936, 2013.

장연희, 최상원, 조성희. 고지방식이 급여 흰쥐에서 대황 및 대황정제환의 혈청 지질 개선 효과. 한국영양학회지, 41 :

$5-12,2008$.

전희영, 김정기, 서대방, 이상준. 클로로필 $\alpha$ 가 UVB 유도성 산화적 스트레스에 matrix metalloproteinases (MMPs) 활 성화 및 콜라겐 합성에 미치는 영향. 한국식품과학회지, 41: 700-705, 2009.

주식회사 엘지생활건강. 미세먼지 차단용 화장료 조성물. 10-1855-4380000. 2017.05.12.

한해나, 엄성환, 김지훈, 김덕훈, 김송희, 김윤혜, 염승목, 김영목. 대황(Eisenia bicyclis)추출액의 항산화 및 항염증 활성

에 대한 유산균 발효의 영향. 한국수산과학회지, 48: 151-157, 2015.

훠리스트 주식회사. 다기능성 썬 제형조성물. 10-2020-0025673, 2018.08.31. 


\section{中文摘要}

\section{大黄和芦荟提取物和二氧化钛混合化合物的多功能防晒霜的新型组成}

金東明 ${ }^{1 *}$, 鄭珠英 $^{1}$, 李灐坤 $^{1}$, 朴相根 ${ }^{1}$, 權容聖 $^{1}$, 梁承九 $^{2}$, 韓仁錫 $^{3}$

${ }^{1} \mathrm{KJM}$ 生物有眼公司生物工学研究所，首尔，韩国

${ }^{2}$ Kim Jung Moon芦荟有限公司芦荟研发中心，首尔，韩国

犹他大学工程学院化学工程系, 盐湖城, 美国

目的: 通过将Eisenia bicyclis (E.bicyclis)和Aloe vera (A. vera)的提取物与微米级和纳米级二氧化钛 $\left(\mathrm{TiO}_{2}\right.$ ) 粉末（MP-100和MPT-136）混合制造多功能新型防晒霜(Novel Composition of Multi-Functional Sunblock, NCMFS)。方法: 将微米级的 $\mathrm{TiO}_{2}$ 和纳米级的 $\mathrm{TiO}_{2}$ 颗粒混合制备复合物。NCMFS是通过将大黄和芦荟提取物与 混合的化合物混合来制备的。分析了混合化合物的理化性质（颗粒形状和大小）以及每种化合物的UV，红外

(IR) 和热阻滞效率。结果: 混合化合物的理化性质分析表明, MP-100和MPT-136的最佳混合比例为 $2.5: 7.5$ 。 对A. vera, E.bicyclis，混合提取物和NCMFS的防晒系数（SPF）和UV-A（PA）防护等级的测量表明, NCMFS 混合物的最高值分别为 $34.35 \pm 0.36$ 和 $34.87 \pm 0.36$ 。同样, 在测量SPF和PA值时, NCMFS的最高值分别为 $34.39 \pm 0.41$ 和 $34.37 \pm 0.52$, 并与每种单一化合物或混合化合物的值进行比较。另外, 发现NCMFS具有优异的 抗细粉尘粘附率和防水性能。结论: 结果表明, 由 $\mathrm{TiO}_{2}$ 和大黄和芦荟提取物组成的NCMFS不仅具有UV, IR和热 阻隔活性, 而且还具有防尘和防水性能。

关键词: 大黄, 芦荟, N-heterocyclic，多功能，防晒霜 